\title{
軸方向およびピッチング加振される磁気ヘッド-回転フロッ ピーティスク連成系の振動ならびにその安定性について*
}

\author{
江 鐘 偉*1, 長 南 征 二*2
Vibration and Stability of a Read/Write Head Floppy Disk System Subjected to External Axial and Pitching Oscillations

\author{
Zhongwei JIANG and Seiji CHONAN
}

\begin{abstract}
This paper is a study of the vibration and stability of a read/write head disk system subjected to external disturbances. The analytical solution is obtained by applying the modal expansion method to the disk governing the equations. In the analysis, the read/write head is modeled as a mass-spring system and the stiffness of the air film in the disk cover is approximated by the stiffness of uniform springs resting under the disk. The axial and the pitching sinusoidal excitations are considered as external disturbances. It is shown that the frequency range where the system has a high response amplitude is affected significantly by the location of the $\mathrm{R} / \mathrm{W}$ head on the disk. Furthermore it is noted that there is an optimum value of the air film stiffness in disk cover to stabilize the whole disk system over a wide range of operating speeds.
\end{abstract}

Key Words: Vibration, Stability, Floppy Disk, Read/Write Head, Axial and Pitching Distur. bances, Optimum Value

\section{1. 緒言}

近年, 工学の進歩に伴いコンピュータが走行体，例 えば自動車, 船, あるいは飛行機などに積載される機 会が增えている。これに伴いコンピュータの外部記憶 装置であるフロッピーディスク装置の防振対策が重要 な課題となってきている。

回転ディスクおよびフロッピーディスク装置に関す る研究はこれまでいくつかなされている.Jwan-Stahl ${ }^{(1)}$ は静止ディスクと回転ば㱛一質量系よりなる連成系の 振動を解析し，ディスクの自由振動応答々求めた。さ らにIwan-Moeller (2)は静止ば孙一質量系を有する回 転ディスクにつきその安定性を理論解析した。また Benson-Bogy ${ }^{(3)}$ は内周をハブに固定された回転円桖の 静止横荷重に対する応答を求めた。 また小野, 前野と 海老原 ${ }^{(4)}$ はディスクカバー中汇納められ，かつ集中静 止横荷重を受ける回転ディスクの振動応答を有限要素 法を用いて解析している。また Hutton·ChonanLehmann ${ }^{(5)}$ は静止横荷重を受け入れる回䎐ディスク に弾性ガイドを当て,ディスクの安定性に及活すガイ

* 平成元年1月24日 第 955 回講演会においで粼演, 原稿受 付 昭和 63 年 6 月 6 日.

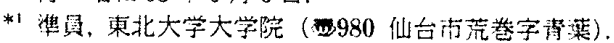

*2 正員, 東北大学工学部,
ドの影響を調べな。さらに長南と江 ${ }^{(6)}$ は軸方向および ピッチング加振される回転ディスクにつき, その定常 応答特性を理論解析した。また江と長南 ${ }^{(7)}$ は R/W ッドを有するディスクの自由振動特性およびその安定 性について調べ, ディスクのライナカバー内の空気膜 がディスクの安定性に大きな影響を与えることを明ら かにしている。

本研究はこれらの問題の一つとして軸方向拉よびピ ッチング加振される磁気ヘッドー回転フロッピーディ スク連成系を取り上げ，外部入力に対してディスクが いかに応答するかを理論により明らかにするものであ る、具体例として 5.25 inch フロッピーディスクを取 り上げ数值計算を行う. 結果より，R/Wへッドの位置 によりディスクの強制振動特性がかなり変化するこ と, ディスクカバー内の空気膜の弾性定数にはディス クを安定化するための最適な值があることが明らかに される。

\section{2. 理 論 解 析}

図 1 は一定角速度 $\Omega$ で時計回りに回転している， 外径 $r=a$ で自由, 内径 $r=b$ で固定されたフロッピ 一ディスク示したものである。ディスクはシャフト を中心に回転し，同時にディスク装置全体が変位 
1158 軸方向拉よびビッチング加振される磁気ヘッドー回転フロッピーディスク連成系の振動ならびにその安定性について

$w_{0}=A_{a} \cos \omega t+A_{p}(r / a) \cos \eta \cos \omega t \quad \cdots(1)$ で加振されている.ここに $A_{a}$ と $A_{p}$ はそれてれ，軸方 向およびディスクのある直径を中心にして回転するピ ッチングの強制変位であり, $\omega$ 治強制変位の振動数で ある.さててディスクのヘッドをばね一質量系でモデル 化し、ディスクカバー中で空気膜で支持されたディス クを, 弾性係数 $x$ のばね床で全面支持されたディスク にモデル化して考える。以下ディスクとへッドの相対 変位を観察するため, 次の三つの座標系を導入する。 すなわち，ディスクとともに回転するが軸方向座標は 空間に固定された座標系を $(z, r, \theta)$ ，回転ディスクに 固定された座標系を $(w, r, \theta)$, ちよび回転しないケ 一スに固定された座標系を $(u, r, \eta)$ とする。ここに半 径 $r$ は三者に共通であり, $z, w, u$ は軸方向の座標で ある、以下これらの変数はその座標に関する変位をも 同時に表すこととする.

$z$ と $w$ の関係沈次式で結び付いている.

$z=w+w_{0}$

ヘッドとディスクが常に接触していると仮定する と,ヘッドがディスクに加える横方向荷重 $q$ は

$$
\begin{aligned}
& q(r, \theta, t)=-\left[m_{L} \partial^{2} z / \partial t^{2}+k_{L}\left(z-w_{0}\right)\right] \\
& \quad \times\left[\delta\left(\theta-\theta_{0}-\Omega t+2 \hat{n} \pi\right) / r\right] \delta(r-\xi)
\end{aligned}
$$

ここで $m_{L}$ と $k_{L}$ はへッドの等洒質量とばね係数であ $\eta,\left(\xi, \theta_{0}\right)$ はディスクに対するへッドの付加位置であ

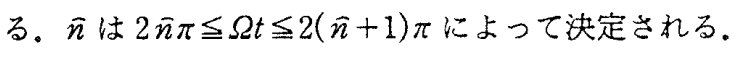
さて, 回転ディスクに固定した座標系 $(w, r, \theta)$ よ り見た場合の，R/Wヘッドを有する回転ディスクの 強制振動方程式は次のように得られる。

$$
\begin{aligned}
& D D^{4} w+\rho h \partial^{2} w / \partial t^{2}+\rho h \partial^{2} w_{0} / \partial t^{2}+x w \\
& \quad-h\left[(1 / r)(\partial / \partial r)\left(r \sigma_{r} \partial w / \partial r\right)\right. \\
& \left.\quad+(1 / r)^{2}(\partial / \partial \theta)\left(\sigma_{\theta} \partial w / \partial \theta\right)\right] \\
& \quad=-\left(m_{L} \partial^{2} w / \partial t^{2}+m_{L} \partial^{2} w_{0} / \partial t^{2}+k_{L} w\right) \\
& \quad \times\left[\delta\left(\theta-\theta_{0}-\Omega t+2 \bar{n} \pi\right) / r\right] \delta(r-\xi)
\end{aligned}
$$

ここに，Dは曲げこわさ，hは板厚さを表す。 $\sigma_{r}, \sigma_{\theta}$ は それぞれ回転により生じる半径方向面内力と周方向面

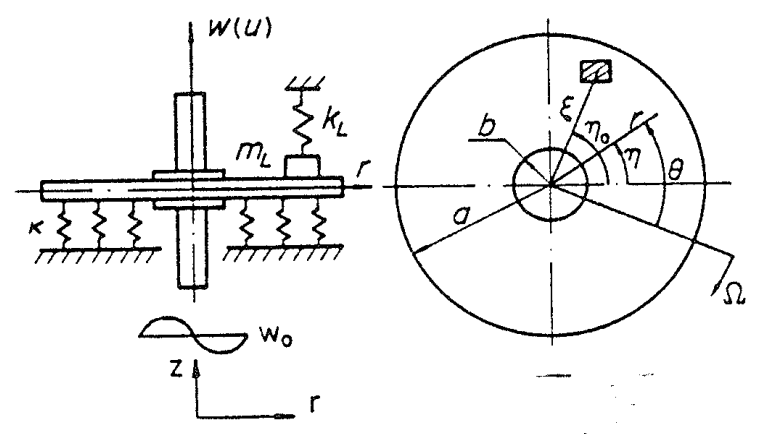

図 1 ヘッドと接触する回転ディスクの座標系
内力である。

ディスクと W/Rヘッドの相対応答を表すため, 次 の関係式

$$
\begin{aligned}
& \theta=\eta+\Omega t-2 \tilde{n} \pi \\
& w(r, \theta, t)=u(r, \eta, t) \\
& \sigma_{r}(r, \theta)=\sigma_{r}(r, \eta), \quad \sigma_{\theta}(r, \theta)=\sigma_{\eta}(r, \eta) \\
& \partial^{m} w / \partial r^{m}=\partial^{m} u / \partial r^{m}, \quad \partial^{m} w / \partial \theta^{m}=\partial^{m} u / \partial \eta^{m} \\
& \partial^{m} w / \partial t^{m}=(\partial / \partial t-\Omega \partial / \partial \eta)^{m} u \\
& \partial^{m} w_{0} / \partial t^{m}=(\partial / \partial t)^{m} w_{0}(r, \eta, t) \cdots \cdots \cdots \cdots \cdots \cdots \cdots \cdots \cdots
\end{aligned}
$$

を用いて, 式 (4)を回転座標系 $(w, r, \theta)$ より,ディ スクケースに固定された座標系 $(u, r, \eta)$ に変換する. すなわち

$$
\begin{aligned}
& D D^{4} u+\rho h\left(\partial^{2} / \partial t^{2}-2 \Omega \partial^{2} / \partial \eta \partial t+\Omega^{2} \partial^{2} / \partial \eta^{2}\right) u \\
& \quad+x u-h\left[(1 / r)(\partial / \partial r)\left(r \sigma_{r} \partial u / \partial r\right)\right. \\
& \left.\quad+(1 / r)^{2}(\partial / \partial \eta)\left(\sigma_{\eta} \partial u / \partial \eta\right)\right] \\
& \quad+\left[m_{L}\left(\partial^{2} / \partial t^{2}-2 \Omega \partial^{2} / \partial \eta \partial t+\Omega^{2} \partial^{2} / \partial \eta^{2}\right) u\right. \\
& \left.\quad+k_{L} u\right] \delta\left(\eta-\eta_{0}\right) \delta(r-\xi) / r \\
& \quad=-\rho h \partial^{2} w_{0} / \partial t^{2}-m_{L} \partial^{2} w_{0} / \partial t^{2} \\
& \quad \times \delta\left(\eta-\eta_{0}\right) \delta(r-\xi) / r \ldots \ldots \ldots \ldots \ldots \ldots \ldots(
\end{aligned}
$$

上式の解を

$$
\begin{gathered}
u(r, \eta, t)=\sum_{m=0}^{M} \sum_{n=0}^{N}\left[C_{m n}(t) \cos (n \eta)\right. \\
\left.+S_{m n}(t) \sin (n \eta)\right] R_{m n}(r / a) \quad \ldots \ldots
\end{gathered}
$$

とおく.ここに $C_{m n}(t), S_{m n}(t)$ は時間の未知関数, $R_{m n}(r / a)$ は境界条件を満足する変位モード関数, $m$ は節円の数, $n$ は節直径の数を表す: $M, N$ は級数解の 項数である。いま, $R_{m n}(r / a)$ として, 静止円板のモ一 ド関数を用いるとすると, それらはベッセル関数を用 いて次式のように表される。

$$
\begin{gathered}
R_{m n}(r / a)=J_{n}\left(k_{m n} r / a\right)+F_{m n} Y_{n}\left(k_{m n} r / a\right) \\
\quad+G_{m n} I_{n}\left(k_{m n} r / a\right)+H_{m n} K_{n}\left(k_{m n} r / a\right)
\end{gathered}
$$

ここで $J_{n}$ と $Y_{n}$ はそれぞれ第 1 種, 第 2 種ベッセル関 数, $I_{n}$ と $K_{n}$ は変形べッセル関数である. $F_{m n}, G_{m n}$, $H_{m n}$ および $k_{m n}$ は境界条件によって决定される定数 である。

さて，式(6)を解くに当たり，始めに式(7)を式 (6)に代入,さらにrR $R_{q l}(r) \cos (\eta n) d \eta d r$ を掛け, $r$ に関して $a$ から $b$ まで, $\eta に$ 関して 0 から $2 \pi$ まで積 分すると，次式を得る。

$$
\begin{aligned}
& \sum_{m=0}^{M} \sum_{n=0}^{N}\left[\alpha_{m n} \partial^{2} C_{m n} / \partial T^{2}+\varepsilon_{m n} \partial^{2} S_{m n} / \partial T^{2}\right. \\
& \quad+\lambda_{m n} \partial C_{m n} / \partial T+\mu_{m n} \partial S_{m n} / \partial T \\
& \left.\quad+\phi_{m n} C_{m n} \tau_{m n} S_{m n}\right]_{q l}=f_{q l} \cos \omega_{0} T \\
& \quad q=0,1,2, \cdots, M: l=0,1,2, \cdots, N
\end{aligned}
$$

同様に $r R_{q l}(r) \sin (l \eta) d \eta d r$ を掛けて積分すると

$$
\sum_{m=0}^{M} \sum_{n=0}^{N}\left[\bar{\varepsilon}_{m n} \partial^{2} C_{m n} / \partial T^{2}+\bar{\alpha}_{m n} \partial^{2} S_{m n} / \partial T^{2}\right.
$$


$+\bar{\mu}_{m n} \partial C_{m n} / \partial T+\bar{\lambda}_{m n} \partial S_{m n} / \partial T$

$\left.+\bar{\tau}_{m n} C_{m n}+\bar{\phi}_{m n} S_{m n}\right]_{q l}=\bar{f}_{q l} \cos \omega_{0} T$

$q=0,1,2, \cdots, M ; l=1,2, \cdots, N$

$こ こ に$

$$
\begin{aligned}
& \alpha_{m n}=\left\langle R_{m n}^{2}\right\rangle \delta_{m q} \delta_{n l}+m_{L 0}\left\langle C_{n} R_{m n}^{q l}\right\rangle \beta_{t} \\
& \bar{\alpha}_{m n}=\left\langle R_{m n}^{2}\right\rangle \delta_{m q} \delta_{n l}+m_{L 0}\left\langle S_{n l} R_{m n}^{q l}\right\rangle \\
& \varepsilon_{m n}=m_{L 0}\left\langle S_{n} C_{l} R_{m n}^{q l}\right\rangle \beta_{l} \\
& \bar{\varepsilon}_{m n}=m_{L 0}\left\langle C_{n} S_{L} R_{m n}^{q l}\right\rangle \\
& \lambda_{m n}=2 n \Omega_{0} m_{L 0}\left\langle S_{n} C_{t} R_{m n}^{q l}\right\rangle \beta_{l} \\
& \bar{\lambda}_{m n}=-2 n \Omega_{0} m_{L 0}\left\langle C_{n} S_{i} R_{m n}^{q l}\right\rangle \\
& \mu_{m n}=-2 n \Omega_{0}\left\langle R_{m n}^{2}\right\rangle \delta_{m q} \delta_{n l}-2 n \Omega_{0} m_{L 0}\left\langle C_{n l} R_{m n}^{q l}\right\rangle \beta_{l} \\
& \bar{\mu}_{m n}=2 n \Omega_{0}\left\langle R_{m n}^{2}\right\rangle \delta_{m q} \delta_{n l}+2 n \Omega_{0} m_{L 0}\left\langle S_{n l} R_{m n}^{q l}\right\rangle \\
& \phi_{m n}=\left(k_{m n}^{4}+x_{0}-n^{2} \Omega_{0}^{2}\right)\left\langle R_{m n}^{2}\right\rangle \hat{\delta}_{m q} \delta_{n l}+\left\langle\sigma R_{m n}^{q l}\right\rangle \delta_{n l} \\
& +\left(k_{L 0}-n^{2} \Omega_{0}^{2} m_{L 0}\right)\left\langle C_{n l} R_{m n}^{q l}\right\rangle \beta_{l} \\
& \bar{\phi}_{m n}=\left(k_{m n}^{4}+x_{0}-n^{2} \Omega_{0}^{2}\right)\left\langle R_{m n}^{2}\right\rangle \delta_{m q} \delta_{n l}+\left\langle\sigma R_{m n}^{q l}\right\rangle \delta_{n l} \\
& +\left(k_{L 0}-n^{2} \Omega_{0}^{2} m_{L 0}\right)\left\langle S_{n l} R_{m n}^{a l}\right\rangle \\
& \tau_{m n}=\left(k_{L 0}-n^{2} \Omega_{0}^{2} m_{L 0}\right)\left\langle S_{n} C_{l} R_{m n}^{q l}\right\rangle \beta_{l} \\
& \bar{\tau}_{m n}=\left(k_{L 0}-n^{2} \Omega_{00}^{2} m_{L 0}\right)\left\langle C_{n} S_{l} R_{m n}^{q l}\right\rangle \\
& f_{q l}=A_{a} \omega_{0}^{2}\left\langle r R_{q l}\right\rangle \delta_{l 0}+A_{p} \omega_{0}^{2}\left\langle r^{2} R_{q l}\right\rangle \delta_{l l} \\
& +m_{L 0} \omega_{0}^{2}\left(A_{a}+A_{p} \bar{\xi} \cos \eta_{0}\right)\left\langle C R_{q l}\right\rangle \beta_{l} \\
& \bar{f}_{q \ell}=m_{L 0} \omega_{0}^{2}\left(A_{a}+A_{p} \bar{\xi} \cos \eta_{0}\right)\left\langle S R_{q l}\right\rangle \\
& \left\langle R_{m n}^{2}\right\rangle=\int_{b / a}^{1}(r / a) R_{m n}^{2} d(r / a) \\
& \left\langle\sigma R_{m n}^{q l}\right\rangle=\int_{b / a}^{1}-\left\{[\partial / \partial(r / a)]\left[(r / a) \sigma_{r 0} \partial R_{m n} / \partial(r / a)\right]\right. \\
& \left.-l^{2} /(r / a) \sigma_{\eta 0} R_{m n}\right\} R_{q} d(r / a) \\
& \left\langle r^{\rho} R_{m n}\right\rangle=\int_{b / a}^{1}(r / a)^{p} R_{m n} d(r / a) \\
& \left\langle C_{n l} R_{m n}^{q l}\right\rangle=\cos \left(n \eta_{0}\right) \cos \left(l \eta_{0}\right) R_{m n}(\xi) R_{q l}(\bar{\xi}) \\
& \left\langle S_{n l} R_{m n}^{q l}\right\rangle=\sin \left(n \eta_{0}\right) \sin \left(l \eta_{0}\right) R_{m n}(\bar{\xi}) R_{q l}(\bar{\xi}) \\
& \left\langle C_{n} S_{l} R_{m n}^{q l}\right\rangle=\cos \left(n \eta_{0}\right) \sin \left(l \eta_{0}\right) R_{m n}(\bar{\xi}) R_{q l}(\bar{\xi}) \\
& \left\langle S_{n} C_{l} R_{m n}^{q l}\right\rangle=\sin \left(n \eta_{0}\right) \cos \left(l \eta_{0}\right) R_{m n}(\bar{\xi}) R_{q l}(\bar{\xi}) \\
& \left\langle C_{l} R_{m n}^{q l}\right\rangle=\cos \left(l \eta_{0}\right) R_{q l}(\bar{\xi}) \\
& \left\langle S_{l} R_{m n}^{q l}\right\rangle=\sin \left(l \eta_{0}\right) R_{q l}(\bar{\xi})
\end{aligned}
$$

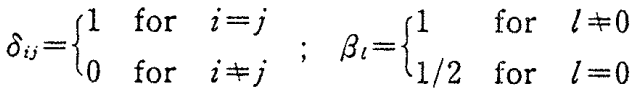

上式において無次元化パラメータは次のように与えら れる.

$$
\begin{aligned}
& T=\left(D / \rho h a^{4}\right)^{1 / 2} t, \quad \Omega_{0}=\left(\rho h a^{4} / D\right)^{1 / 2} \Omega \\
& \sigma_{r 0}=\left(h a^{2} / D\right) \sigma_{r}, \quad \sigma_{\eta 0}=\left(h a^{2} / D\right) \sigma_{\eta} \\
& \chi_{0}=\left(a^{4} / D\right) x, \quad \omega_{0}=\left(\rho h a^{4} / D\right)^{1 / 2} \omega \\
& m_{L 0}=m_{L} / \rho h a^{2} \pi, \quad k_{L 0}=\left(a^{2} / \pi D\right) k_{L} \\
& \tilde{r}=r / a, \quad \vec{\xi}=\xi / a
\end{aligned}
$$

式 (9)と式(10)をまとめてマトリックスで表すと

$$
\sum_{m=0}^{M} \sum_{n=0}^{N}\left[\begin{array}{cc}
\alpha_{m n} & \varepsilon_{m n} \\
\bar{\varepsilon}_{m n} & \bar{\alpha}_{m n}
\end{array}\right]\left\{\begin{array}{l}
\ddot{C}_{m n} \\
S_{m n}
\end{array}\right\}+\left[\begin{array}{cc}
\lambda_{m n} & \mu_{m n} \\
\bar{\mu}_{m n} & \bar{\lambda}_{m n}
\end{array}\right]\left\{\begin{array}{l}
\ddot{C}_{m n} \\
S_{m n}
\end{array}\right\}
$$

$$
+\left.\left[\begin{array}{cc}
\phi_{m n} & \tau_{m n} \\
\bar{\tau}_{m n} & \widetilde{\phi}_{m n}
\end{array}\right]\left\{\begin{array}{l}
C_{m n} \\
S_{m n}
\end{array}\right\}\right|_{q l}=\left\{\begin{array}{l}
f_{q l} \\
\bar{f}_{q l}
\end{array}\right\} \cos \omega_{0} T
$$

\section{式(13)の解を}

$$
\begin{aligned}
& {\left[C_{m n}, S_{m n}\right]^{T}=\left[C_{m n}^{1}, S_{m n}^{1}\right]^{T} \cos \omega_{0} T} \\
& \quad+\left[C_{m n}^{2}, S_{m n}^{2}\right]^{T} \sin \omega_{0} T \ldots \ldots \ldots \ldots .
\end{aligned}
$$

とおくとディスクの横変位は

$u=A \cos \omega_{0} T+B \sin \omega_{0} T$

で与えられる。ここに

$$
\begin{aligned}
& A=\sum_{m=0}^{M} \sum_{n=0}^{N}\left(C_{m n}^{1} \cos n \eta+S_{m n}^{1} \sin n \eta\right) \\
& B=\sum_{m=0}^{M} \sum_{n=0}^{N}\left(C_{m n}^{2} \cos n \eta+S_{m n}^{2} \sin n \eta\right)
\end{aligned}
$$

\section{3. 計 算 結 果}

数值計算例として, 5.25 inch フロッピーディスク を取り上げ以下, ディスクの直径 $2 a=130.18 \mathrm{~mm}$, 内 径 $2 b=32.78 \mathrm{~mm}$, 厚さ $h=0.077 \mathrm{~mm}$, 密度 $\rho=1.40$ $\mathrm{g} / \mathrm{cm}^{3}$, ヤング率 $E=5300 \mathrm{~N} / \mathrm{mm}^{2}$, ポアソン比 $\nu=$ 0.3 および級数解の項数を $M=3, N=6$ として計算を 行う．市販されているフロッピーディスク装置につい

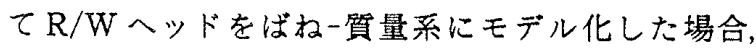
その等価質量圮よび等価ばね定数はそれぞれ $m_{L}=$ $4.15 \mathrm{~g}, k_{L}=38.58 \mathrm{~N} / \mathrm{m}$ (無次元化量は $m_{L 0}=2.89, k_{L 0}$ =234.816) ともとまる.

図 2 はディスクケースが軸方向に加振された場合， $\mathrm{R} / \mathrm{W}$ ヘッドの位置の変化によるフロッピーディスク の応答振幅の変化を示す、いずれもへッド取付位置て の変位を示す。加振振動数 $f(=\omega / 2 \pi)$ は 0 - $500 \mathrm{~Hz}$, ディスクの回転数は $\Omega=300 \mathrm{rpm}$ である。図 2(a)は ヘッドが $\left(\bar{\xi}, \eta_{0}\right)=(0.5,0)$ にある場合, 図 $2(\mathrm{~b}),(\mathrm{c})$ は各に $\left(\xi, \eta_{0}\right)=(0.7,0),(0.9,0)$ の場合を示す。図から わかるように R/W ヘッドの位置が移動してもフロッ ピーディスクの共振振動数はあまり影響されないが, $\mathrm{R} / \mathrm{W}$ ヘッドが外周方向に移動するに從い,フロッピ 一ディスクに大きな振幅を生じさせる加振振動数領域 が低い振動数域へ集中していくことがわかる。この傾 向をディスクの防振対策に㐫用するとすれば、へッド が $\bar{\xi}=0.5$ にあるときは $0 \sim 200 \mathrm{~Hz}$ 域の入力を遮断す ればよいこと, $\bar{\xi}=0.9$ のときは0〜 $100 \mathrm{~Hz}$ 域の入力 を遮断する必要のあることを示している。

図 3 はディスクケースがピッチング強制変位を受け る場合の, ヘッドの位置の変化によるディスクの応答 変位の変化を示す、数値計算ではピッチング入力は, $=\pi / 2$ の直径を中心として回転するピッチング変位と 
1160 軸方向およびピッチング加振きれる磁気ヘッドー回転フロッピーディスク連成系の振動ならでにその安定性について

仮定している。図 3(a) 脑ヘッドが $\left(\bar{\xi}, \eta_{0}\right)=(0.7,0)$ に ある場合, 図 $3(\mathrm{~b})$ 流 $\left(\bar{\xi}, \eta_{0}\right)=(0.7, \pi / 2)$ の場合, すな わちへッドがピッチング強制変位のノード上にある場 合を示す.ピッチング加振振動数は0〜 $500 \mathrm{~Hz}$, ディ スク回転数は $\Omega=300 \mathrm{rpm}$ である。軸方向加振の場合 と同様に, R/W ヘッドの位置が変化してもディスク の共振振動数にはあまり変化のないことがわかる。こ の二つの場合振幅の大きさを比べてみると,ヘッドが $\eta_{0}=\pi / 2$ にあるとき図3(b)]の活うが, 全体として 振幅が図 3(a)より小さくなっている．特にこの場合， 高い加振振動数における変位振幅の小さいことがわか る、これはへッドがピッチング強制変位のノード上に あるためである。これよりピッチング入力の大きい状
況下では，ディスクヘッドがピッチングノードにくる ようにディスク装置を設置すべきであることが言え ろ.さらに図 3(a) と図 $2(\mathrm{~b})$ を比較してみると、ピッ チング加振の場合は軸方向加振の場合より，ディスク の振幅が小きくなっていることがわかる。

図 4 はディスクが軸方向加振される場合の，ディス クカパー内の空気膜こわさ $x_{0}=500$ に対するディスク の応答振幅を示す。ヘッドの位置および回転数はそれ ぞれ $\left(\bar{\xi}, \eta_{0}\right)=(0.7,0), \Omega=300 \mathrm{rpm}$ である. 図 2(b) と 比較してみると, カバーの弾性係数 $\varkappa_{0} か ゙ 10$ 倍になっ ているにもかかわらず，共振振動数と振幅応答はあま り変化が見られない，文献（7）ではディスクカパー内 の空気膜の剛性が, 単体で回転するディスクの安定性

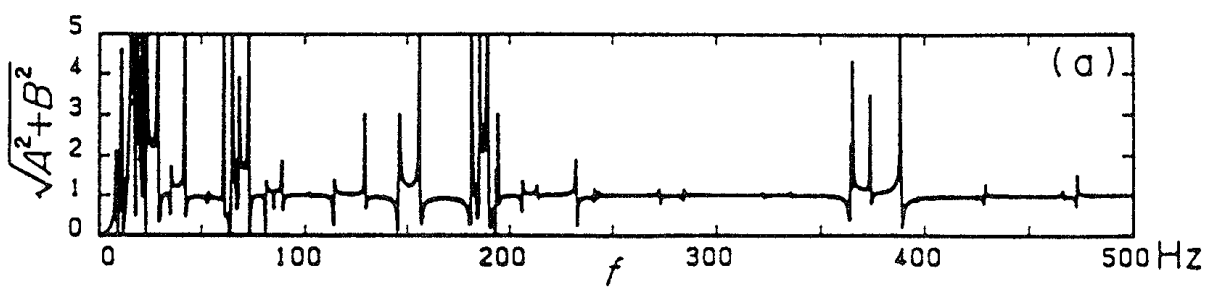

$\left(\bar{\xi}, n_{0}\right)=(0.5,0)$
$(\bar{r}, n)=(0.5,0)$
$m_{L 0}=2.89$
${ }_{L}=234.816$
$\kappa_{O}=50, \Omega=300 \mathrm{rpm}$

$\left(\bar{\xi}, n_{0}\right)=(0.7,0)$

$(\bar{r}, n)=(0.7,0)$

$m_{L O}=2.89$

$k_{L 0}=234.816$

$K_{0}=50, \Omega=300 \mathrm{spm}$

$\left(\vec{\xi}, n_{0}\right)=(0,9,0)$

$(\bar{r}, n)=(0.9,0)$

$m_{L 0}=2.89$

$k_{L_{0}}=234.816$

$x_{0}=50, \Omega=300=\mathrm{pm}$

図 2 軸方向加振によるフロッピーディスクの振幅応答

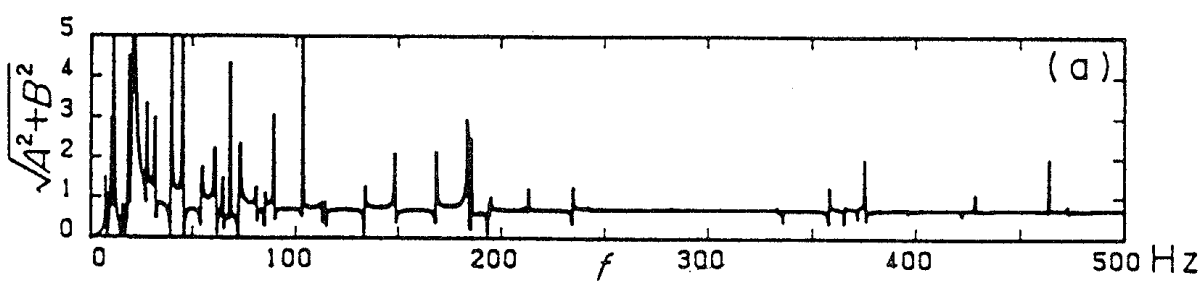

$\left(\bar{\xi}, n_{0}\right)=(0.7,0)$

$(\vec{r}, n)=(0.7,0)$

$m_{L 0}=2.89$

$K_{L 0}=234.816$

$\kappa_{0}=50, \Omega=300 \mathrm{spm}$

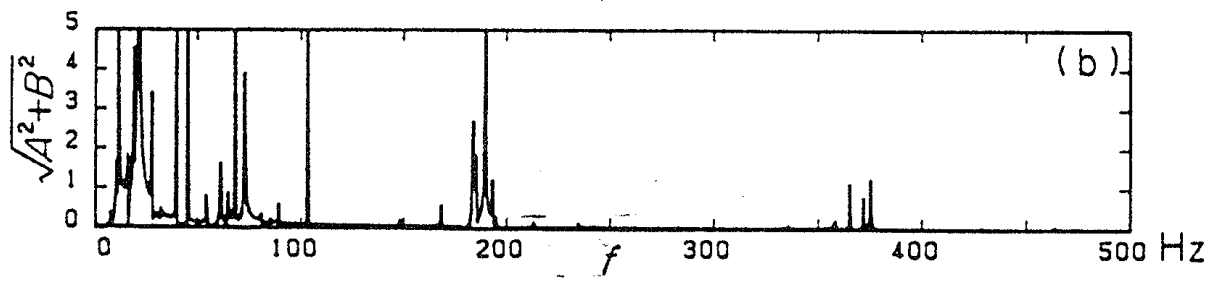

$\left(\vec{\xi}_{,}, n_{0}\right)=(0.7, \pi / 2)$

$(\bar{r}, \eta)=(0.7, \pi / 2)$

$m_{L 0}=2.89$

$k_{L O}=234.816$

$K_{0}=50, \Omega=300 \mathrm{rpm}$

図 3 ピッチング加振によるフロッピーディスクの振幅応答 

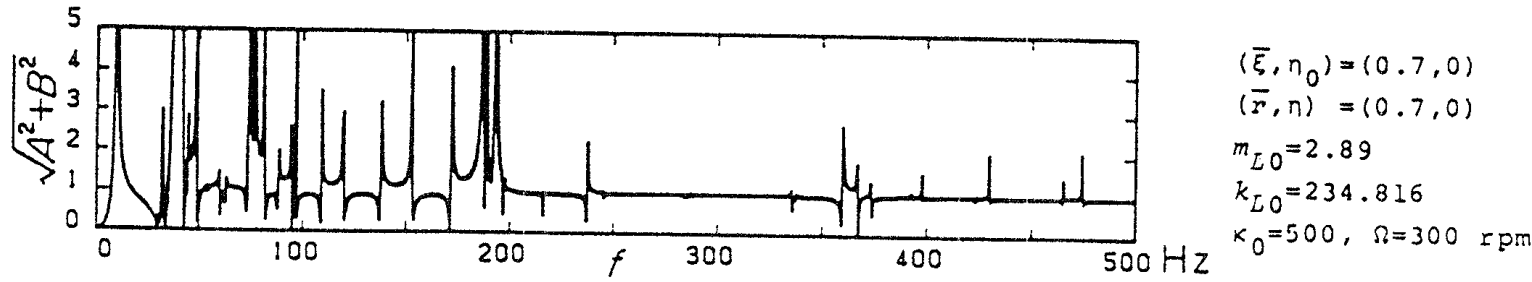

図 4 軸方向加振におけ村る $\kappa_{0}=500$ に対するフロッピーディスクの振幅応答

に大きな役割を及ほすことが示されているが,ここで も R/Wへッドを有するディスクの安定性が $x_{0}$ の值 にいかに影響されるかを調べてみ上う。

図 5 は $m_{L 0}=2.89, k_{L 0}=234.816, x_{0}=0 \sim 500$ の場合 につき,ディスクに不安定現象の表れる危険回転数を ヘッドの半径位置 $\bar{\xi}$ 関数として示したものである. ディスクは $\vec{r}=0.2518$ で内周固定されているため図 5 では $\vec{\xi}=\vec{r} \geqq 0.2518$ の領域について結果が示されて いる. 図 5 を説明する前にまず図 6,7 について少し説 明しておく。図 6 と図 7 は $m_{L 0}=2.89, k_{L 0}=234.816$ 人 ッドとディスクの接触位置 $\left(\vec{\xi}, \eta_{0}\right)=(0.7,0)$ の場合に つき, 無次元複素固有振動数とディスクの回転速度の 関係を示す. 図 6 での実線㹥本解析法の級数解法儿基 づいて求めた結果, 破線は単一モードの近似解の結果 を表す(7). 図6ではディスクカバーの弾性の影響を考 慮していない $\left(x_{0}=0\right)$ が, 図7では $x_{0}=50$ としてい る. $x_{0}$ が零のとき(図 6 ), ディスクの回転数が約 $\Omega_{0}=$ 0.5 のところで振動数の虚数部分の曲線が上下合体し， これ以上の回転数でフラッタ形の不安定が生じてい る.しかし $x_{0}=50$ とすると(図 7)，それらの曲線は上 下合体せず，安定領域も一気に約 $\Omega_{0}=4.2$ まで広がり， $\Omega_{n}=4.2$ を超えるところでダイバジェンス形不安定が 現れてくる. 図 5 の場合， $x_{0}$ の值が 40 以下ではへッド がディスクハブの近くにあるとき(例之ば 合）ダイバジェンス不安定によりディスクは高い危険 回転数を有するが、ヘッドがディスク外周へ移動する と，あるそでダイバジェンス不安定が起こる前にフラ ッ夕不安定が現れるためディスクの危険回転数はかな り低くなり，図のように危険回転数の曲線は不連続と なる。 メ の值が 50 以上となると，ダイバジェンス形不 安定域の前に見られるフラッタ形不安定域がすべて消 滅してしまうためディスクの危険回転数はヘッドの位 置にかかわらずかなり高くなることがわかる。しかし， 単に $x_{0}$ が大きいほど危険回転数が高いというわけで なく，例えば， $x_{0}=100,500$ のとき，へッドの位置が $\bar{\xi}$ $=0.5$ より大きくなるとディスク危険速度は逆に下が っている、したがって、フロッピーディスクカバー内 の空気膜の剛性にはディスクを高回転数まで安定化す

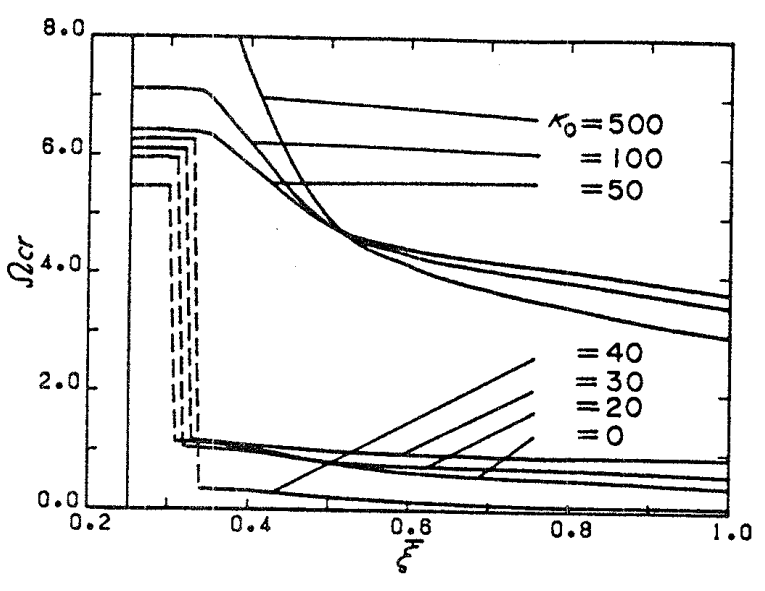

$\left(m_{t .0}=2.89, k_{t .0}=234.816\right)$

図 5 ディスクの危険回転数 $\Omega_{\mathrm{cr}}$ とヘッドの半径 位置 $\vec{\xi}$ の関係

るための最適な值があることがわかる。

\section{4. 結 論}

本研究は $\mathrm{R} / \mathrm{W}$ ヘッドを有するフロッピーディスク 装置が外部加振される場合のディスクの振動応答, お よびフロッピーディスクのナイラカバー内の空気膜弾 性がディスクの安定性に及ほすす影響について理論解析 したものである。得られた結果を要約すると次のよう になる。

（1）フロッピーディスク装置が外部加振きれると

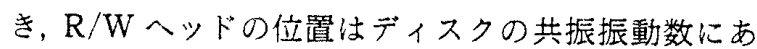
まり影響を与えない。しかしながら軸方向加振の場合 はヘッドが半径方向にディスク外周へ移動するに従 い,フロッピーディスクに大きい応答振幅をもたらす 加振領域は振動数の低い領域へ集中していく。

（2）ピッチング加振の場合はヘッドが円周方向に ピッチングノードの位置に近づくに従い全体として振 幅が小さなり，特に高い加振振動数域における变位 振幅が小さくなる。これよりピッチング入力の大きい 状況下では，ディスクヘッドがピッチングノードにく るようにディスク装置を設置すべきであることが言え る.

（3）ディスクカバー内の空気膜の剛性はディスク 

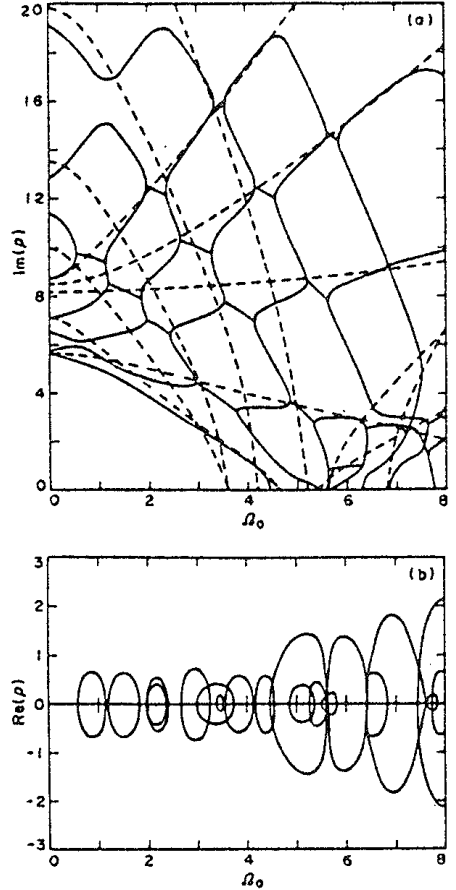

$\left(m_{L 0}=2.89, k_{L, 0}=234.816, \bar{\xi}=0.7, \eta_{0}=0, x_{0}=0\right)$

図 6 回転数 $\Omega_{0}$ による複素固有振動数 $p$ の変化

の共振振動数にもあまり影響しないが、ヘッドを有す るディスクシステムの安定性には大きな役割を果たし ている。さらにヘッドに対して，ディスクカバーの内 の空気膜の剛性にはディスクを安定化するための最適 な值が存在する。

終わりに臨み，本解析におきまして終始想切なご指 導を賜りました東北大学 阿部博之教授に厚く感謝の 意を表します。また本研究を遂行するに当たり，フロ ッピーディスクならびに磁気ヘッドに関する資料を提 供していただいた東北アルプス(怢)，岩永 敦氏に厚 くお゙礼申し上げます。
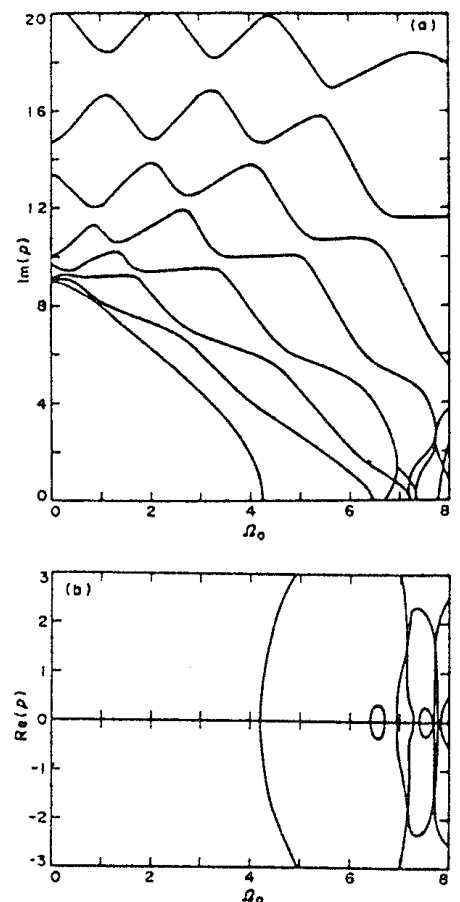

$\left(m_{L 0}=2.89, k_{L 0}=234.816, \bar{\xi}=0.7, \eta_{0}=0, x_{0}=50\right)$

図 7 回転数 $\Omega_{0}$ による複素固有振動数 $p$ の変化

\section{文献}

(1) Iwan, W. D. and Stahl, K. J., Trans. ASME, J. Appl. Mech.. 95 (1973), 445.

(2) Iwan, W. D. and Moeller, T. L., Trans. ASME, J. Appl. Mech., 43 (1976), 485.

(3) Benson, R. C. and Bogy, D. B., Trans. ASME, J. Appl. Mech., 45 (1978), 636

（4）小野・ほか 2 名，機論，52-473，C(昭 61)，326.

(5) Hutton, S. G., Chonan, S. and Lehmann, B. F., J. Sound. Vib., 112-3 (1987), 527.

（6）辰南・江，㙨論，54-502，C（昭 63），1181.

（7）江・長南，機論, 54-507，C (昭 63)，2669. 